\title{
Kamuya Açılan Sınıf: Mesleki Mahremiyet ve Uzaktan Eğitimde Gözetlenme
}

\author{
DOI: $10.26466 /$ opus. 896351
}

\author{
$*$ \\ Taner Atmaca* $^{*}$ Erdal Yıldırım ** - Turgay Öntaş *** \\ ${ }^{*}$ Doç. Dr. Düzce Üniversitesi, Eğitim Fakültesi, Düzce/Türkiye \\ E-Posta: taneratmaca@duzce.edu.tr \\ ORCID: $\quad$ 0000-0001-9157-3100 \\ ** Dr. Öğr. Üyesi, Aksaray Üniversitesi, Eğitim Fakültesi, Aksaray/Türkiye \\ E-Posta: Erdal.yildirim@gmail.com ORCID: 0000-0002-8726-5903 \\ *** Doç. Dr., Namık Kemal Üniversitesi, SHMYO, Tekirdağ/Türkiye \\ E-Posta: turgayontas@gmail.com ORCID: 0000-0003-2258-0862 \\ Öz
}

Bu çalışmanın amacı Covid-19 salgını ile yaygınlaşan uzaktan ve dijital eğitim-öğretim faaliyetleri esnasında ortaya çıkan mahremiyet ihlali algısı ve dijital gözetime ilişkin öğretmenlerin deneyimlerini ve görüşlerini ortaya çıkarabilmektir. Bu bağlamda Türkiye'nin farklı coğrafi bölgelerinde ve illerinde çalışan toplamda 24 öğretmenle yarı yapılandırılmış görüşme tekniğgi ile veriler elde edilmiştir. Bu çalışmada nitel araştırma yaklaşımı içinde yer alan bütüncül tekli durum deseni kullanılmıştır. Araştırmanın çözümlenmesinde içerik analizinden yararlanılmıştır. Öne çıkan bulgular arasında bu süreçte öğretmenlerde mahremiyete ilişkin kaygıların arttı̆̆ı görülmektedir. Sinıf içinde yani kamusal alanda kalması gereken öğretmen-öğrenci ilişki ve diyaloglarının izleyen herkese açık hale gelmesi mesleki mahremiyet algısını da olumsuz etkilemektedir. Bununla birlikte mesleğe yabancılaşma, yüksek kaygı, huzursuzluk, gözetilmenin verdiği endişe, ailelerin sürece karışması de yer almaktadır. Uzaktan eğitimin öğretmenlik mesleğinde öğretme heyecanını kaybettirdiği de görülmektedir. İzlenmenin öğretmenlerde bir baskı unsuruna dönüştüğ̈̈ de bulgulardan anlaşılmaktadır. Mesleki mahremiyet bilincinin güçlendirilmesi bu süreçte önemli sayılmaktadır. Araştırmanın sadece öğretmenlerle sinırl olması ve öğrenci ya da aileler ile görüşme yapılmamış olması çalışmada sınırlılık olarak ele alınabilir.

Anahtar Kelimeler: Mesleki Mahremiyet, Gözetim, Uzaktan Eğitim. 


\title{
Classroom Opening to the Public: Professional Privacy and Surveillance in Distance Education
}

\begin{abstract}
The aim of this study is to reveal the experiences and opinions of teachers regarding the perception of privacy violation and digital surveillance that emerged during the distance and digital education activities that became widespread with the Covid-19 outbreak. In this context, Turkey's different geographical areas and data with semi-structured interview technique to teach a total of 24 workers in the province were obtained. In this study, the holistic single case design, which is included in the qualitative research approach, was used. Content analysis was used to analyze the research. Among the prominent findings, it is seen that concerns about privacy among teachers increased during this process. The fact that teacher-student relationships and dialogues, which should remain in the classroom, ie in the public sphere, become open to everyone who watches also negatively affect the perception of professional privacy. In addition, alienation from the profession, high anxiety, uneasiness, anxiety caused by being observed, and interference of families in the process are also included. It is also seen that distance education loses the enthusiasm of teaching in the teaching profession. It is understood from the findings that monitoring has turned into an element of pressure for teachers. Strengthening professional privacy awareness is considered important in this process. The fact that the study was limited to only teachers and no interviews were made with students or families can be considered as a limitation in the study.
\end{abstract}

Keywords: Professional Privacy, Surveillance, Distance Education. 


\section{Giriş}

Dijitalleşmeyle birlikte internetin ve internete bağlanma özelliği olan nesnelerin toplumsal ve gündelik hayatın hemen her yerine girmiş olması ve kullanımının yaygınlaşması bazı tanımlamaları da beraberinde getirmiştir. Örneğin ağ toplumu (Castells, 2013), şeffaflık toplumu (Chul-Han, 2019), denetim toplumu (Deleuze, 1992), gözetim toplumu (Foucault, 2007) gibi topluma ilişkin yeni betimlemeler söz konusudur. Özellikle dijitalleşmenin ortaya çıkardığı her yerde ve her zaman ulaşılabilirlik durumu görünürlüğün artmasını sağladığından şeffaflık olarak tabir edilen olguyu ortaya çıkarmış ve kamusal alana ait olanı kamusal alanın dışına taşımıştır. Zaman ve mekânın sınır koymadığı ulaşılabilirlikle ortaya çıkan sürekli gözetim tekinsiz bir durumu, kaygı halini, özele ait olanı yani mahremi yabancıların bakışına maruz bırakmayı da beraberinde getirmiştir ve yabancının bakışına hapsolan kişi özgürlügünden uzaklaşmaya başlamıştır (Poyraz, 2019). Bu durum ise büyük ölçüde gözetlenmeyle ilişkilidir.

Modernite ile ilişkilendirilen önemli kavramlardan biri olan panoptikon gözetlenen toplumu, yani bir merkezden herkesin gözetlenmesini ifade etmektedir ve Foucault'un (2019) dikkat çektiği önemli konulardan biridir. Foucault, modern panoptikonlar olarak okulları, hapishaneleri, fabrika ve orduyu örnek vermektedir (Foucault, 2019; Şentürk ve Turan, 2012; Şişman, 2019). Bu bağlamda okul bir gözetleme merkezidir ve aynı zamanda disipline edici yani bedenler ve zihinler üzerine hegemonya kurucu güce de sahiptir, çünkü gözetim aynı zamanda disipline edici bir forma sahiptir. Böylece iktidar toplumsal alanın her yerine yayılır ve kişiler iktidarın farklı formları ile birçok şekilde karşı karşıya gelebilirler (Yücedağ, 2017). Ancak gözetimin her ne kadar bu yönü olsa da fiziksel ve mekânsal sınırlar onu kamusal alan sınırlaması içinde tutmakta ve okulda olup bitenler kamusal alanın mahremiyetini içermektedir. Günümüz toplumunda ise tek merkezden gözetim değil çoklu gözetimler yani sinoptikon ve omniptikon söz konusudur. Küresel çaptaki bu gözetimde, panoptikondan farklı olarak omniptikonda görünür olmanın hazzı söz konusudur, farklı anlatımla kişi kendini gönüllü olarak görünür kılmaktadır (Okmeydan, 2017). Böyle bir durumda Bauman'a göre (2018) kurban olmakla şöh- 
ret olmak aynı anlama gelmektedir. Zira Chul-Han'a göre (2019) her mesafe şeffaflık toplumunda ortadan kaldırılması gereken bir olumsuzluk olarak görülmektedir ve günümüz toplumu mesafeleri ortadan kaldıran bir etkileşimi önemsemektedir. Bunun da gerisinde büyük ölçüde gelişen teknoloji vardır (McLuhan, 2005) ve böylece insan-insan etkileşimi "ben ve öteki" arasındaki ilişkiyi, kamusallığı dönüştürmüş durumdadır (Şişman, 2019). Çünkü, Yücedağ'ın da (2017) altını çizdiği şekliyle toplumsal ilişkiler kişilerin tek başlarına kurgusunu gerçekleştirdikleri bir hakikat olmanın ötesinde etkileşime dayalı bir özellik göstermektedir.

Gözetim ve buna bağlı olarak ortaya çıkan denetim, tarih içinde toplumların hayatlarında farklı formları ile görünmüştür. Dijitalliğin toplumsal hayatın her alanını çepeçevre kuşatması gözetlenenler için çeşitli kaygılar ve korkular oluşturduğu gibi kimileri içinse iktidarın gözünün üzerlerinde olması bir güvence olarak kabul edilmektedir, çünkü modern toplumda artan belirsizlik ve riskin ortaya çıaracağı zararın gözetlenme ile bertaraf edileceği düşünülmektedir (Yücedağ, 2017). Dijital teknolojinin gözetimde gittikçe yaygınlaşması gözetimi, yüz yüze ve doğrudan disiplin edici bir formundan çıkarıp uzaktan disipline edici bir forma dönüştürmektedir. Ancak bu sürekli gözetim hali ve gözetim ağının gittikçe her yere ulaşması bir yandan çeşitli kolaylıklar ve güvenliğe dayalı kaygıları giderici meşruiyet oluştursa da bir yandan da gizlilik ve mahremiyetin sınırlarını ortadan kaldırmaktadır. Bu bağlamda Bauman (2017) zaman ve mekânın insanın kontrolünden çıkıp "akışkan" bir forma büründüğünü dile getirmektedir. Ancak Bauman ve Lyon'un (2020) ve Chul-Han'in (2019) dikkatleri çektiği farklı bir nokta ise özellikle sosyal medya platformlarında gözetlenmekten ve görünmekten bireyin haz duyması ve bu platformlara herhangi bir zorunluluk olmadan bireyin kendi özeline ait olanı kamuya açık hale getirmesi, gözetlenmeye ve denetlenmeye karşı kayıtsız hale gelmesi yani gözetlenmeye karşı bilinçli rıza üretimidir. Sürekli gözetim hali bilinçli veya bilinçsiz bir denetimi içselleştirme ve buna bağlı bir davranış değişikliğine gitmeyi gerektirebilir. Lyon (2006, 2013) ise gözetlemeyi etki, ikna ve ayartma olarak ifade etmektedir ve önleyici gözetleme ile disipline edici yani denetime dayalı olmak üzere iki farklı gözetlemeden söz etmektedir ve ikinci gözetleme her yere yayılabilen, genişleme gücü yüksektir, "denetim toplumu" oluşturmaya dönüktür. Lace (2005) günümüz bireyini şeffaf, kırılgan, gözetlenebilir, gözetleyenlerin 
hakkında çok şey bildiği ve gözetlenmekten memnun varlıklar olarak belirtmektedir. Filozof Sarte (2009) ise ünlü "Varlık ve Hiçlik" eserindeki Bakış adlı felsefi denemesinde başkasının bakışını, varlığa derinden nüfuz eden, benim dünyamı benim olmaktan çıkaran, yabancının bakışının / gözetiminin kişiyi başkalaştıran ve benim sandığımı düşündüğüm dünyamı elimden alan bir özelliğe de haiz olduğunu belirtmektedir (Poyraz, 2019).

Kamusal ve toplumsal alanda yürütülen işler kendi içerisinde bir mahremiyet çerçevesi içermektedir, zira mahremiyet bir sınır çizme işlemidir ve sınırın ötesinde bulunan ile içinde bulunan arasındaki ayrımı da ortaya koymaktadır (Gündoğan, 2019). Kamusal alan içinde "başkası" tarafından seyredilmek aradaki ilişkiyi akışkan hale getirmek ve nesneleşmek anlamına gelmektedir. Zira bu kamusal alan gözetlendiğimiz ve görünür olduğumuz alandır; kamusal alanı, özel alandan ayıran temel ölçütlerden birisi görünür olmasıdır (Özbek, 2004) ve bu alanlarda gözetlenilen kişinin alanda mahremiyeti gitmiş, kendiliği kaybolmuş, doğal davranışı yerini koşullu davranışa bırakmıştır (Gündoğan, 2019). Siber gelişmelerin ortaya çıkardığı toplumda ise mahremiyetin ifşası bir gönüllü yıkımdır (Hazır, 2019). Baudrillard (2020) kaybolan bu hakikatin yerine gelen sanal hakikati simülasyon olarak nitelemekte ve bunun gittikçe daha çok ön plana geçtiğini dile getirmektedir. Reyes (2017) ise içinde bulunduğumuz bu dijital çağı "post-truth era" (hakikat sonrası çağ) şeklinde betimlemektedir.

Dünya genelinde 2019 yılının başlarından itibaren etkisini gösteren Covid-19 salgını, fiziki yakınlık ve temas gerektiren eğitimde pek çok alı̧̧kanlığın değişmesine yol açmıştır (Rapanta vd. 2020). Öğretmenlerin, öğrencilerin ve ailelerin salgin öncesindeki durumdan koparak yeni normal olarak tabir edilen uygulamalara hızlı uyum sağlamalarının hiç de kolay olmadığ1 görülmektedir. Salgından önceki dönemlerde de değişen öğrenme-öğretme platformlarına ve pratiklerine alışkın olmayan öğretmen ve öğrencilerin yaşadıkları bazı zorluklara literatürde değinilmektedir (Bennett ve Lockyer, 2006). Ancak bu zorlukların pek çoğu teknik kısımlar olan nitelikli ve kesintisiz bağlantı kurabilme, içerik hazırlama, dijital platformlara yeteri kadar hâkim olamama, uygulama gerektiren derslerin yürütülememesi gibi durumları kapsamaktadır (Akyavuz ve Çakın, 2020; Can, 2020; Çelik, 2020; Kahraman, 2020). Bu süreçle birlikte dijital içerik tasarımı, eğitimsel teknolojiyi kullanabilme ve yönetebilme, dijital veriler 
ve etik gibi konular tartış1lır hale gelmiştir (Bozkurt, 2020). Salgınla birlikte yaygınlaşan uzaktan eğitim sürecinde yeteri kadar tartışılmadığ 1 düşünülen konulardan birisi de eğitimin ve öğretimin dijital platformlara taşınması ile mekânsal sınırların ortadan kalkması, ebeveynlerce uzaktan gözetim ve denetimin artması, öğretmenler açısından mesleki mahremiyetin aileler tarafından ihlal edilmesi ve bunlara bağlı olarak ortaya çıktığ 1 düşünülen çeşitli pedagojik kaygılardır. Başka anlatımla geleneksel metotta otoriteyi temsilen gözetleyen konumundaki bir özne iken öğretmenler, uzaktan eğitimde gözetlenenler olmuşlardır. Eğitim fiziksel mekânından uzaklaşarak yani sınırlı ve kontrollü alanından çıkarak dijital alana, gözetime, şeffaflığa, denetime ve çoklu kontrole açı hale gelmiştir. Toplumsal yaşamın ve karşılaşmaların mekanlar içinde olduğu geçtiğimiz dönemlerde toplumsal kontrolü ve gözetimi mekanlar üzerinden yapma fikri esastı (Baştürk, 2016). Ancak günümüz toplumunda gözetim, mekânın ve zamanın sınırlayıcı etkisinden çıarak her yerdelik ve süreklilik özelliği kazanmıştır. Lyon'un (2006:37) deyimiyle modern zamanlarda "kendimiz" ve dolayısıyla özel olarak düşünülen bedenlerimiz bile gözetleme için kaynak haline gelmiştir. Eğitim de bu Covid-19 salgını sürecinde toplumsal yaşamın önemli karşılaşma mekanlarından olan okullardan dijital ortamlara taşınmıştır ve bu taşınmanın kademeli olarak değil de aniden gerçekleşmesi beraberinde bazı pedagojik ve sosyolojik sonuçları ortaya koyduğu düşünülmektedir. Bunlar arasında ise öğretmenlerin başkaları tarafından sürekli gözetlenir, denetlenir ve kontrol edilir hale gelmeleri ve buna bağlı ortaya çıan kaygı ve çekincelerin ön sıralarda yer aldığ 1 tahmin edilmektedir.

Bu araştırma Türkiye'de Covid-19 salgını ile dijital ortamlara taşınan eğitim-öğretim faaliyetlerinin şeffaf, gözetlenir ve denetlenir hale gelmesinin ve aileler tarafından daha fazla görünür olmasının öğretmenlerin mesleki mahremiyetini etkilediği ve buna bağlı olarak da çeşitli kaygılarıkorkuları ortaya çıkardığı düşüncesine dayanmaktadır. Öğretmenlerin geleneksel ve yüz-yüze eğitim süreçlerinde aktif özneler ve aktörler olarak sahnede, ön planda yer alırken yeni normalle uzaktan ve herkesçe izlenilebilen birer aktöre dönüşmesi ve buna henüz hazır olmamalarının ortaya çıkardığı durumlar bu araştırmanın odağını ve problemini oluşturmaktadır. Bu bağlamda aşağıdaki sorulara cevaplar aranmıştır: 
- Covid-19 salgını sürecinde eğitim-öğretim faaliyetlerinin uzaktan ve dijital ortamlarda sürdürülmesine bağlı olarak gözetlenme-izlenmeye bağlı ortaya çıkan pedagojik kaygılar söz konusu mudur?

- Uzaktan ve gözetime açık eğitim-öğretim pratikleri mesleki mahremiyeti olumsuz etkilemekte midir?

\section{Yöntem}

\section{Araştırmanın Modeli}

$\mathrm{Bu}$ araştırma, nitel araştırma metodolojisine göre tasarlanmıştır ve bütüncül tekli durum çalışması desenine göre gerçekleştirilmiştir. Merriam (2013) durum çalışmalarını sınırlı bir sistemin derinlemesine incelenmesi olarak nitelendirmekte ve durum çalışmalarının yoğun betimleme özelliğine dikkat çekmektedir. Patton (2014:450) durum çalışmalarını, "okuyanı durumun içine ve deneyime yani grubun yaşantısına götürmelidir" şeklinde betimlemektedir. Yin'in (2017) altını çizdiği üzere durum çalışmaları gerçek ve güncel bir durumu, gerçek yaşam alanına yansıyan biçimiyle irdelemeyi gerektirir. Durum çalışması, Yin'e (2017) göre güncel bir olayı derinlemesine, kendi özgün ortamı içinde incelemeyi kapsamaktadır ve belirli bir durumun sosyal dünyasına zengin bir yaklaşım sunarak var olan olayların iç yüzünü gösteren bir bakış açısı katmaktadır. Yıldırım ve Şimşek'e (2013) göre durum çalışmaları ise araştırmacının kontrol edemediği durumları derinlemesine irdelemesi ile ortaya çımasına olanak vermektedir.

\section{Çalışma Grubu}

Araştırmaya toplamda 24 kişi katılmıştır. Çalışma grubu maksimum çeşitlilik örneklemesi ile oluşturulmuştur. Maksimum çeşitliliği sağlama adına katılımcıların yaş, branş, cinsiyet, çalıştıkları kademe ve şehir, okul türü, mesleki kıdem, istihdam biçimleri ve eğitim düzeyleri esas alınmıştır. Katılımcıların çeşitli demografik özelliklerine ilişkin dağılım Tablo 1 'de sunulmuştur. 
Tablo 1. Örneklem grubunun demografik özellikleri

\begin{tabular}{|c|c|c|c|c|c|c|c|c|c|c|}
\hline Sira & Kod & $\begin{array}{l}\text { Cinsi- } \\
\text { yet }\end{array}$ & Yaş & Kademe & Branş & $\begin{array}{l}\text { Okul } \\
\text { Türü }\end{array}$ & $\begin{array}{l}\text { K1- } \\
\text { dem }\end{array}$ & İstihdam & Şehir & $\begin{array}{l}\text { Eğitim } \\
\text { Düzeyi }\end{array}$ \\
\hline 1 & Ö1 & Erkek & 43 & İlkokul & Kimya & Devlet & $15 Y_{11}$ & Kadrolu & Ankara & Lisans \\
\hline 2 & Ö2 & Erkek & 38 & Ortaokul & Türkçe & Devlet & $10 Y_{11}$ & Kadrolu & Bolu & Lisans \\
\hline 3 & Ö3 & Kadın & 31 & Ortaokul & $\begin{array}{l}\text { Bilişis } \\
\text { T. }\end{array}$ & Devlet & $7 Y_{11}$ & Kadrolu & Ankara & Lisans \\
\hline 4 & Ö4 & Kadın & 35 & İlkokul & $\begin{array}{l}\text { Sinıf } \\
\text { Öğr. }\end{array}$ & Özel & $12 \mathrm{Y}_{11}$ & Kadrolu & İstanbul & Master \\
\hline 5 & Ö5 & Erkek & 30 & İlkokul & $\begin{array}{l}\text { Sinıf } \\
\text { Öğr. }\end{array}$ & Devlet & $6 Y_{11}$ & Ücretli & Ankara & Lisans \\
\hline 6 & Ö6 & Erkek & 54 & Lise & $\begin{array}{l}\text { Mate- } \\
\text { matik }\end{array}$ & Devlet & $30 \mathrm{Y}_{11}$ & Kadrolu & Erzurum & Lisans \\
\hline 7 & Ö7 & Kadın & 47 & Lise & Grafik & Devlet & $19 Y_{11}$ & Kadrolu & İstanbul & Lisans \\
\hline 8 & Ö8 & Erkek & 36 & Ortaokul & $\begin{array}{l}\text { Din } \\
\text { Kül. }\end{array}$ & Devlet & $6 \mathrm{Y}_{11}$ & Kadrolu & Ankara & Lisans \\
\hline 9 & Ö9 & Kadın & 39 & İlkokul & $\begin{array}{l}\text { Sinıf } \\
\text { Öğr. }\end{array}$ & Devlet & $14 Y_{11}$ & Kadrolu & İzmir & Master \\
\hline 10 & Ö10 & Erkek & 40 & İlkokul & $\begin{array}{l}\text { Sınıf } \\
\text { Öğr. }\end{array}$ & Devlet & $18 Y_{11}$ & Kadrolu & Ankara & Lisans \\
\hline 11 & Ö11 & Kadın & 40 & İlkokul & $\begin{array}{l}\text { Sinıf } \\
\text { Öğr. }\end{array}$ & Devlet & $20 Y_{11}$ & Kadrolu & İstanbul & Lisans \\
\hline 12 & Ö12 & Kadın & 41 & Ortaokul & Fen Bil. & Devlet & $19 Y_{11}$ & Kadrolu & Ankara & Master \\
\hline 13 & Ö13 & Erkek & 50 & Ortaokul & $\begin{array}{l}\text { Beden } \\
\text { Ĕg. }\end{array}$ & Devlet & $26 Y_{11}$ & Kadrolu & Düzce & Lisans \\
\hline 14 & Ö14 & Erkek & 43 & Lise & Tarih & Devlet & $20 Y_{11}$ & Kadrolu & Ankara & $\mathrm{PhD}$ \\
\hline 15 & Ö15 & Kadın & 40 & İlkokul & $\begin{array}{l}\text { Sinıf } \\
\text { Öğr. }\end{array}$ & Devlet & $18 Y_{1}$ & Kadrolu & Sivas & Lisans \\
\hline 16 & Ö16 & Kadın & 31 & Ortaokul & $\begin{array}{l}\text { Bilişim } \\
\text { T. }\end{array}$ & Devlet & $7 Y_{1 l}$ & Kadrolu & Aksaray & Lisans \\
\hline 17 & Ö17 & Kadın & 32 & İlkokul & $\begin{array}{l}\text { Sinıf } \\
\text { Öğr. }\end{array}$ & Devlet & $7 Y_{1 l}$ & Ücretli & Ă̆r1 & Lisans \\
\hline 18 & Ö18 & Erkek & 38 & İlkokul & $\begin{array}{l}\text { Sınıf } \\
\text { Öğr. }\end{array}$ & Devlet & $16 Y_{11}$ & Kadrolu & Ankara & Master \\
\hline 19 & Ö19 & Erkek & 48 & Lise & Fizik & Devlet & $26 Y_{11}$ & Kadrolu & Rize & Master \\
\hline 20 & Ö20 & Kadın & 41 & İlkokul & $\begin{array}{l}\text { Sinıf } \\
\text { Öğgr. }\end{array}$ & Devlet & $20 Y_{11}$ & Kadrolu & Ankara & Master \\
\hline 21 & Ö21 & Kadın & 45 & Ortaokul & $\begin{array}{l}\text { Mate- } \\
\text { matik }\end{array}$ & Devlet & $21 Y_{1}$ & Kadrolu & Bursa & Lisans \\
\hline 22 & Ö22 & Erkek & 45 & İlkokul & Din K. & Devlet & $21 Y_{1}$ & Kadrolu & Ankara & Lisans \\
\hline 23 & Ö23 & Kadın & 34 & İlkokul & $\begin{array}{l}\text { İngi- } \\
\text { lizce }\end{array}$ & Özel & $8 Y_{11}$ & Kadrolu & İstanbul & Master \\
\hline 24 & Ö24 & Erkek & 64 & Lise & $\begin{array}{l}\text { Beden } \\
\text { Ĕg. }\end{array}$ & Devlet & $40 \mathrm{Y}_{11}$ & Kadrolu & Ankara & Lisans \\
\hline
\end{tabular}

Tablo 1'e bakıldığında araştırmaya katılan öğretmenlerin yarısının erkek (n:12), yarısının kadın (n:12), en gencinin 30 yaşında, en ileri yaştakinin 64 yaşında olduğu, 12'sinin ilkokul kademesinde, 7'sinin ortaokul ve 5 'inin de lise kademesinde görevli olduğu görülmektedir. Katılımcıların 
9'unun sınıf öğretmeni, 2'sinin matematik öğretmeni, 2'sinin bilişim teknolojileri öğretmeni, 2'sinin beden eğitimi, 2'sinin din kültürü öğretmeni olduğu; kimya, Türkçe, grafik, fen bilimleri, tarih, fizik ve İngilizce branşlarında ise 1 öğretmenin katılımcı olduğu görülmektedir. Katılımcıların büyük çoğunluğu (n:22) devlet okullarında, daha az sayıda katılımcı ise (n: 2) özel okullarda çalışmaktadır. Mesleki kıdem açısından bakıldığında ranjın 6 ile 40 yıl arasında değiştiği görülmektedir. Katılımcıların büyük çoğunluğu kadrolu (n:22) çalışan iken daha az sayıda katılımcı ücretli / geçici (n:2) olarak çalışmaktadır. 16 öğretmen lisans düzeyinde, 7 öğretmen yüksek lisans düzeyinde, 1 öğretmen de doktora düzeyinde eğitime sahiptir. Katılımcılar Türkiye'nin 11 farklı ilinde görev yapmaktadır.

\section{Veri Toplama Araçları}

Araştırmada, yarı yapılandırılmış görüşme formu veri toplama aracı olarak kullanılmıştır. Sorular oluşturulmadan önce araştırma problemi ile ilgili literatürde yer alan çalı̧̧malar gözden geçirilmiş ve belirlenen anahtar kavramlar etrafında ana sorular oluşturulmuştur. Oluşturulan sorular sosyoloji ve eğitim bilimlerinde uzman 3 farklı öğretim üyesine uzman görüşü alınmak üzere gönderilmiş, gelen çeşitli uyarı ve düzeltmeler neticesinde sorulara son hali verilmiştir. Katılımcılarla görüşmeler gerçekleştirilirken çeşitli sonda soruları da ilave edilmiştir. Görüşmelerde kullanılan bazı örnek sorulara aşağıda yer verilmiştir:

Soru 1: Uzaktan ders işlerken gözetlendiğinizi düşünüyor musunuz, neden? Evet ise, bu durum sizde ne gibi hisler oluşturmaktadır?

- Gözetlendiğinize yönelik yaşadığınız örnekler var mı? Varsa nasıl gelişti, neler hissettiniz?

Soru 2: Gözetlenmek derslerinize nasıl yansımaktadır? Ders işleyişinizi nasıl etkilemektedir?

Soru 3: Kimler tarafından gözetlendiğinizi düşünüyorsunuz?

-Gözetlenme daha çok nasıl gerçekleşmektedir?

- Aileler veya okul yönetiminin gözetlemesi arasında ne gibi farklılıklar olmaktadır?

Soru 4: Öğretmenlerin bu süreçte daha rahat olabilmeleri için neler yapilmalıdır? 


\section{Verilerin Toplanması ve Çözümlenmesi}

Araştırmanın verileri, Aralık 2020-Ocak-2021 periyodu içinde online ve anlık görüşme imkânı sağlayan, görüşmeyi kayıt altına alan platformlarda, bireysel görüşmeler şeklinde gerçekleşmiştir. Katılımcılardan bu araştırmaya gönüllü katıldıklarına ilişkin onam formu Google formları üzerinden alınmıştır. Verilerin çözümlenmesinde betimsel analiz ve içerik analizi tekniği tercih edilmiştir. Betimsel analizde elde edilen veriler, önceden belirlenen temalara göre özet şeklinde verilir ve yorumlanır (Yıld1rım ve Şimşek, 2013). İçerik analizi, verileri temalar ve alt temalar etrafında açıklamaya, verilerin içinde saklı olabilecek gerçekleri görünür hale getirmeye olanak tanımaktadır (Yıldırım ve Şimşek, 2013). İçerik analizi tekniği kullanılarak hacimli nitel veriler, temalar ve örüntüler etrafında tutarlı ve anlamlı bir bütün içinde ele alınabilir (Patton, 2014). Verilerin çözümlenmesinde NVIVO-11 programından yararlanılmıştır.

\section{Geçerlik ve Güvenirlik}

Araştırma geçerliliğini ve güvenirliğini sağlamak için farklı kodlayıcıların uyum birliğini sağlamak adına, araştırmacılardan bağımsız olarak 2 alan uzmanına da ayrıca veriler kodlatılmıştır. Kodlama benzerliğinin yüksek olduğu görülmüştür. Bununla beraber katılımcı teyidi ve doğrudan alıntılar ile güvenirlik ve inandırıcılık artırılmaya çalışılmıştır.

\section{Etik İzin}

$\mathrm{Bu}$ çalışmanın verileri toplanmadan önce veri toplama araçları ve süreci ile ilgili etik bir ihlal olmaması için Aksaray Üniversitesi İnsan Araştırmaları Etik Kurulu'nun 22/02/2021 tarih ve 2021/01-22 sayılı kararı ile gerekli araştırma izinleri alınmıştır.

\section{Bulgular}


Veri analizi sonucunda, dört tema altında on altı kategori kümelenmiştir. $\mathrm{Bu}$ temalar ve kategoriler, bulguları ve bunların yorumlarını bir bütün olarak özetlemek için Tablo 2'de sunulmuştur:

Tablo 2: Mahremiyet sürecinin ihlaline ilişkin görü̈şler

\begin{tabular}{|c|c|c|}
\hline Tema & Kategori & Kodlar \\
\hline \multirow{11}{*}{$\begin{array}{l}\text { Mahremiyetin İhlalinin } \\
\text { Psikolojik etkileri }\end{array}$} & Yabancılaşma & Mekaniklik \\
\hline & & Kaybedilen Heyecan \\
\hline & & Kendisi olamamak \\
\hline & Görmezden Gelme & Önemsememe \\
\hline & & Takılıp kalmama \\
\hline & Güvensizlik & Kuşku \\
\hline & & Güvenirlik \\
\hline & & Kötüye kullanma \\
\hline & Kayg1 & Huzursuzluk \\
\hline & & Çekingenlik \\
\hline & & Bask1 \\
\hline \multirow{11}{*}{$\begin{array}{l}\text { Mahremiyetin İhlalinin } \\
\text { Mesleki Etkileri }\end{array}$} & Ön Yarg1 & Yarg1 dili \\
\hline & & Yanlış algılama \\
\hline & Mesleki özgürlük & Kısıtlanmışlık \\
\hline & Mesleki Saygınlık & Değersizlik \\
\hline & & Mesleğin sorgulanması \\
\hline & & Denetime açıklık \\
\hline & Öğretim Süreci & Veli Desteği/Karışması \\
\hline & & Müdahale \\
\hline & & Destek süreçleri \\
\hline & Rekabet & Öğrenciler arası \\
\hline & & Veliler arasi \\
\hline \multirow[t]{2}{*}{$\begin{array}{l}\text { Mahremiyetin İhlal Süreç- } \\
\text { leri }\end{array}$} & Koşullar ve Neden & $\begin{array}{l}\text { Sosyo-ekonomik nedenler } \\
\text { Merak }\end{array}$ \\
\hline & Gözetlenme Şekilleri & $\begin{array}{l}\text { Veli gözetimi } \\
\text { Araçlar }\end{array}$ \\
\hline
\end{tabular}

\section{Tema 1: Mahremiyetin İhlalinin Psikolojik Etkileri}

Mahremiyetin psikolojik etkileri; yabancılaşma, görmezden gelme, güvensizlik ve kaygı başlıkları altında kategorileştirilerek ayrıntılı değerlendirilmiştir (Tablo 2).

Mahremiyetin psikolojik etkilerinden biri olan yabancilaşma, öğretmenlerin kendine yabancılaşmalarının yanında, öğrenme süreçlerinde canlı ders sistematiğinin mekanik hale getirdiği birer aparat niteliğine büründükleri izlenimini vermektedir. Bu durum, öğretmenlerin insani iliş- 
kilerden kendilerini yalıtmak zorunda kalmalarına yönelik olarak düşünülebilir. Mekanikliğe bağlı kaybedilen heyecan ve anlamsızlık hissi, sürecin öğretmenler üzerinde aşırı dikkat ve oto sansüre neden olduğu ifade edilebilir. Ayrıca süreçte yaşanan belirsizlik ve kuralsızlıkların, öğretmenlerde inisiyatif alamamaya dair normsuzluğa ve paydaşlar karşısında yaşadığ1 güçsüzlüğe de sebep olduğu düşünülebilir.

Mahremiyetin psikolojik etkilerinden biri olan görmezden gelme ise, öğretmenlerin canlı ders esnasında daha çok velilere dayalı yaşadıkları problemleri; kendilerine, öğrencilere ve öğretim sürecine zarar verilmemesi için görmezden gelmelerine dayandırılabilir. Süreçte daha çok velilere dayalı bu görmezden gelmenin, öğretmenlerde süreçte yaşanan problemlere takılıp kalmamak, dersini sabote eden veli profilini önemsememek ya da yaşananlar hiç olmamış gibi kendini baskılayarak yola devam etmek şeklinde yorumlanabilir.

Mahremiyetin bir diğer psikolojik etkilerinden olan güvensizlik, öğretmenlerin uzaktan eğitim süreçlerinde aileler, öğrenciler ve okul idarecileri tarafından amacı beli olmayan gözetlenme durumlarının nasıl kullanılacağına dair kuşkulara dayalıdır. Öğretmenlerin gözetlenme durumlarında yaşadıkları güvensizlik, aileler ve öğrenciler tarafından gözetlenme kayıtlarının aleyhlerine kullanılacağına dayandırılırken, okul idarecilerine dayalı güvensizlik ise bakanlığın ve diğer yetkililerin işine olan bağlılığına ve samimiyetine olan şüphelere yöneliktir. Süreçte öğretmenlerin yaşadıkları güvensizlik durumları, ayrıca paydaşlar tarafından aşağılanma, göz korkutma ve iftiraya uğramaya yönelik çekincelerle de ifade edilmektedir. Öğretmenlerin canlı dersler esnasında daha çok veliler ve kimliği belirsiz kişiler tarafından derslerinin sabote edildiğini, okul idaresinin izinsiz derslere müdahale edişinin ise kendilerinde suçluluk psikolojisi yarattığı düşünülebilir. Ayrıca öğretmenlerin süreçte bütün paydaşlara yönelik güvensizliğinin, kendilerinin her durumda yalnız olduklarına yönelik yaşadıkları korku ile bunun zamanla kanıksanarak duyarsızlık hallerine evirilmesi de sebep olarak gösterilebilir.

Öğretmenlerin uzaktan eğitim süreçlerine yönelik kaygılarının, okulun önemli paydaşlarından olan velilerin ders esnasında öğretim süreçlerinden öğrenciyle kurulan diyaloglara kadar hemen hemen her şeye müdahale edişine ya da edebileceğine yönelik gerilim, rahatsızlık ve huzursuz- 
luğa dayandırılmaktadır. Ayrıca öğretmenlerin ders esnasında yaşanabilecek aksaklıklardan dolayı kendilerine yönelik aşırı dikkat ve baskılarının; kendilerinde hata yapma endişesi, tedirginlik, çekingenlik ve unutkanlıklara da neden olduğu düşünülebilir. Uzaktan eğitim süreçlerinin, veli ve okul idarecilerini memnun etmeye yönelik yetişkin ilişkileri ve diyaloglarındaki ciddiyete evirildiği, bunun da öğretmen ve öğrenci arasındaki otantik iletişim süreçlerini baltaladığı da söylenebilir.

Tablo 3: Mahremiyetin ihlalinin psikolojik etkisine ilişkin kod ve örnek alıntılar

\begin{tabular}{|c|c|c|}
\hline Kategori & Kodlar & Örnek Alıntılar \\
\hline \multirow{3}{*}{ 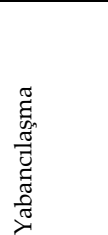 } & Mekaniklik & $\begin{array}{l}\text { Kendimi rahat hissedemiyorum. Öğrencilerimle eğlenceli vakit geçiremiyo- } \\
\text { rum. Çoğu yerde tiyatral bir şekilde konuşmak, şakalaşarak ders işlerim. Ama } \\
\text { şimdi daha ciddiyim. }\end{array}$ \\
\hline & $\begin{array}{l}\text { Kaybedilen He- } \\
\text { yecan }\end{array}$ & $\begin{array}{l}\text { Daha dikkatli davranmak zorunda kalıyoruz. Bazen yapmacık bile olabiliyo- } \\
\text { ruz. Heyecanımı kaybediyorum kendim olamıyorum. }\end{array}$ \\
\hline & $\begin{array}{l}\text { Kendisi olama- } \\
\text { mak }\end{array}$ & Heyecanımı kaybediyorum kendim olamıyorum. \\
\hline \multirow[b]{2}{*}{ 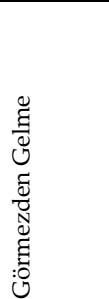 } & Önemsememe & $\begin{array}{l}\text { Bazen herhangi bir baba tarafından gözetlendiğimi düşünüyorum. İşimi yap- } \\
\text { maya çalıştığım için art niyetli bakışları önemsememeye çalışıyorum. }\end{array}$ \\
\hline & $\begin{array}{l}\text { Takılıp Kal- } \\
\text { mama }\end{array}$ & $\begin{array}{l}\text { Ev halkının neredeyse tamamı güya görünmediğini sanarak tek tek ekrana } \\
\text { bakıp geri çekiliyor. Ders esnasında annelerin birçok sorusuna maruz kalıyo- } \\
\text { rum mesela. Babaların güya çocuğuna yardımcı olmak, direktif vermek mak- } \\
\text { satlı derse dâhil olma çabaları da cabası. Maksat ilgilenen baba profili çizer- } \\
\text { ken asıl amacın öğretmene bakmak, onunla sohbet etmek olması da çok üzücü. } \\
\text { Genel anlamda kötü bir his uyandırdığı için rahatsı olduğum durumlarda } \\
\text { kamerayı kapatarak yoluma devam ediyorum. }\end{array}$ \\
\hline \multirow{3}{*}{ 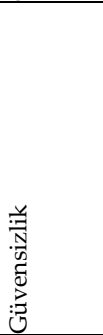 } & Kuşku & $\begin{array}{l}\text { Doğru ya da uydurma bilmiyorum ama bazı öğretmenlerin donan resimleri- } \\
\text { nin medyada dolaştığını duymamdan kaynaklanan bir endişem var. Bana da } \\
\text { yaparlar mı diye korktuğumu söylemek zorundayım. }\end{array}$ \\
\hline & Güvenirlik & $\begin{array}{l}\text { Veli izlemesinden ziyade bakanlık çalışanları ya da okul yönetiminin izlemesi } \\
\text { "bize güvenilmiyor mu" hissi yaratıyor. Veli meraktan ve çocuğuna hitap } \\
\text { eden kişiyi, ders anlatışını tanımak anlamak için izliyor olabilir. Ama her şe- } \\
\text { kilde rahatsız his. }\end{array}$ \\
\hline & $\begin{array}{l}\text { Kötüye Kul- } \\
\text { lanma }\end{array}$ & $\begin{array}{l}\text { Bazen düşünüyorum derslerimin kayıt altına alınıp sonradan sorun teşkil } \\
\text { edecek şekilde yorumlanması fikri rahatsız ediyor. Evet, internetin herkese } \\
\text { açık bir platform olması ve ekranın arkasında neler olduğunu görememek. }\end{array}$ \\
\hline \multirow[b]{3}{*}{ 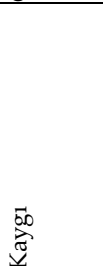 } & Huzursuzluk & $\begin{array}{l}\text { Evet, gözetlendiğimizin hem veli hem de amirlerimiz tarafından yapıldı̆̆ına } \\
\text { inanıyorum. Herhangi bir insani hatanın yapılma olasılığına karşı neyle kart- } \\
\text { şılacağımız karşısında kaygı duymaktayım. }\end{array}$ \\
\hline & Çekingenlik & $\begin{array}{l}\text { Kurduğum cümlelere dikkat etmeye çalışıyorum. Tedirgin oluyorum. Bu du- } \\
\text { rum dikkatimi dağıtıyor. }\end{array}$ \\
\hline & Bask1 & $\begin{array}{l}\text { Evet, aşırı derecede gerilim içindeyiz en basit soruları dahi veliye acık verme- } \\
\text { mek için defalarca okuyup yanlış yapmama gayreti içindeyiz çocukları uyara- } \\
\text { mıyor, şakalaşamıyoruz veli sadece bizi değil birbirini de gözetliyor. }\end{array}$ \\
\hline
\end{tabular}


Uzaktan eğitim, öğretim süreçlerini sınıfların dışına çıkararak mesleki mahremiyeti de sorgulatmaya başlamıştır. Öğretmenlerin canlı derslerdeki öğretim süreçlerine müdahalenin genel anlamda veliler tarafından yapıldığını, bunun da veli desteği, akıl verme ve müdahale şeklinde sıraladıkları görülmektedir. Ayrıca veliler, öğretim süreçlerinden sorumlu öğretmenlerin derslerine müdahale ederek; öğretmenlerde rol karmaşası, rahatsızlık ve gereksizlik hislerine de neden oldukları düşünülebilir. Canlı ders esnasında velilerin öğretim süreçlerine olan kontrol edilemeyen müdahaleleri, öğrenci rekabetinden veli rekabetine evirilerek derslerin amacından saptırılmasına da neden olduğu gözden kaçırılmamalıdır.

\section{Tema 2: Mahremiyetin İhlalinin Mesleki Etkileri}

Öğretmenlerin mesleki mahremiyetini etkileyen önemli kavramlardan biri de önyargıdır. Uzaktan eğitim süreçlerinde öğretmenler tarafından önyargı kavramına yapılan atıflar, veliler ve okul idarecileri tarafından öğretmenlerin yaptıkları uygulamalara yönelik sürekli açık arama, haksız ve dayanıksız eleştiriler ile yanlış algılara dayandırıldığı düşünülebilir. Ayrıca, öğretmenlerin canlı ders esnasında öğrencileriyle olan samimi ve insani ilişkilerinin, veliler tarafından dalga konusu edildiği ve öğretmenin süreçte somut olarak ortaya koyduğu performansın hem veli hem de okul idaresi tarafından sürekli yargı diline maruz bırakıldığı da söylenebilir. Mesleki özgürlüğe dair ifadeler de mesleki mahremiyetin ortadan kalktığını ortaya koyan önemli sonuçlardandır. Öğretmenlerin uzaktan eğitim süreçlerinde veli, okul idaresi ve teknolojiye bağlı olumsuzlukları, mesleki anlamda kısıtlanmalarına neden olarak göstermektedirler. Ayrıca, canlı ders esnasında kendi öğrencileriyle baş başa kalmayan öğretmenlerin, veliler tarafından öğretmen-öğrenci ilişkilerine ve öğrenme süreçlerine olan müdahalelerin de hem öğretmen hem de öğrencilerin sürece adapte olmaları için gerekli ölçülü rahatlığı ortadan kaldırdığına yönelik düşünceler de dikkat çekicidir. Öğretmenlerin meslekleri boyunca edindikleri tecrübelerle inşa ettikleri özgünlükleri de canlı ders süreci boyunca yaşanan olumsuzluklarla ortadan kalktığına yönelik ifadeleri de gözden kaçırılmamalıdir.

Mesleki mahremiyetin ortadan kalktığına işaret eden bir diğer kategori, mesleki saygınlıktır. Öğretmenlerin gözetlenme durumlarını ve 
buna yönelik okulun önemli paydaşlarından olan veli ve okul idarecilerinin süreçteki davranışlarını, mesleki anlamda değersizliğe sebep olan faktörler arasında değerlendirdikleri düşünülebilir. Velilerin uzaktan eğitim süreçlerinde eğitim-öğretim faaliyetlerine yardımcı önemli bir paydaş olma vasfı, öğretmenlerin profesyonelliğini sorgulayan, öğrenciler karşısında değersizleştiren ve onurlarını zedeleyen bazı davranışlarla törpülendiği söylenebilir. Okul idarecilerinin uzaktan eğitim süreçlerindeki rolleri ise, öğretmenlerin mesleki mahremiyetlerine halel getiren habersiz gözetlemeler ve öğretmenlere güvenmediklerini ortaya koyan davranışlarla baltalandığı görülmekte, bunun da öğretmenlerde onur zedelenmesine ve saygısızlığa uğradıklarını düşünmeye yönelttiği ifade edilebilir. Uzaktan eğitim süreçlerinde okulun bütün paydaşları arasında kurulamayan sağlıklı iletişim, öğretmenlerde mesleğini icra ederken daha çok veliler tarafından maruz bırakıldıklarını düşündükleri engellenme ve yetersizlik hislerine de neden olduğu söylenebilir.

Öğretmenlerin mesleki anlamda denetime açıklık faaliyetleri, veliler ve okul idaresi tarafından suiistimal edilerek mesleklerinin sorgulanmasına, asıl amaçları olan öğrencilerine odaklanamamaya ve diğer paydaşlara yönelik takınılan aşırı resmi tavırların öğrencilere de yansıtılmasına neden olduğu düşünülebilir. Ayrıca velilerin rekabetçi tutumları ve öğrencileri yarıştırmaya yönelik tavırları, öğretmenlerin her öğrenciye adil ve eşit bir öğretim süreci sunabilmesinin önünde önemli bir engel olarak düşünülmektedir. Eğitim-öğretim süreçlerinin önemli bir bileşeni ve adeta sağlaması olan geri bildirim, uzaktan eğitim süreçlerinde başarılı olarak yürütülmediğine yönelik öğretmen ifadeleri dikkat çekmektedir. Canlı derslere olan veli müdahalesi, ulaşılmak istenen hedeflere varılıp varılamad1ğına yönelik belirsizliklere neden olmakta ve öğrencilerin birden fazla kaynak tarafından yönlendirilmesi de sağliklı geri bildirim alınabilmesinin önündeki engeller arasında sayılabilmektedir.

Öğretmenlerin uzaktan eğitim süreçlerinde mesleki mahremiyetlerinin korunmasında, destek süreçlerinin de önemli bir payı vardır. İfade edilen destek süreçlerinin, okulun önemli paydaşlarından olan veli ve okul idaresinin uzaktan eğitim süreçlerine yönelik bilinçlendirilmesine odaklandığı söylenebilir. Ayrıca canlı ders güvenirliliğini sağlamak için yerli, bilinen ve kontrol edilen uygulamaların geliştirilmesi ile öğretmen ve öğ- 
rencilerin teknik anlamda desteklenmesine yönelik öneriler de dikkat çekmektedir. Uzaktan eğitim süreçlerinin planlanmasında, öğretmenlerin hassasiyetlerini dikkate alan yaklaşımlar, öğretmelerin toplumdaki mesleki saygınlıklarını ve paydaşlar arasındaki önemlerini artırabilir. Ayrıca, uzaktan eğitim süreçlerine yönelik yaşanan problemler ile bunlara yönelik bilimsel ve kültürel temelleri esas alan çözüm önerileri, paydaşlarla sıklıkla paylaşılabilir.

Tablo 4: Mahremiyetin ihlalinin mesleki etkilerine ilişkin kod ve örnek alıntılar

\begin{tabular}{|c|c|c|}
\hline Kategori & Kodlar & Örnek Alıntılar \\
\hline \multirow[t]{2}{*}{ Önyarg1 } & Yarg1 Dili & $\begin{array}{l}\text { Sınıf benim öğrencilerimle kurduğum özel ortamımdır. Biz orda yeri gelir } \\
\text { güler, yeri gelir ağlar, yeri gelir kılıktan kılığa girer, yeri gelir insani onuru } \\
\text { koruyarak sıkıntılarımızı tartışır, dersimizi işleriz. Dışarıdan biri aramız- } \\
\text { daki o köprüyü o kalp bă̆ını bilmez ve hemen yargı diline geçer. }\end{array}$ \\
\hline & Yanlış Algılama & $\begin{array}{l}\text { Velilerin eleştirileri gözetlendiğim hissi oluşturuyor. Eksik veya yanlış bilgi- } \\
\text { lerle yapılan yorumlar beni üzüyor. Haksızlık gibi geliyor. }\end{array}$ \\
\hline $\begin{array}{l}\text { Mesleki Öz- } \\
\text { gürlük }\end{array}$ & Kısıtlanmışlık & $\begin{array}{l}\text { Sınıf mahremiyeti kalmıyor öğrenci öğretmen arasındaki ilişkiye veli de katı- } \\
\text { lıyor. Öğrenci de rahat edemiyor, özgür kalamıyor. } \\
\text { Öğrenciler bazen aileleri ile birlikteyken canlı derse katıllyorlar. Seslerden } \\
\text { anlayabiliyorsunuz. Uygunsuz bir durum. Kendimi rahat ve özgür hisset- } \\
\text { medim. }\end{array}$ \\
\hline \multirow{3}{*}{$\begin{array}{l}\text { Mesleki } \\
\text { Saygınlık }\end{array}$} & Değersizlik & $\begin{array}{l}\text { Arkada çocuğun dedesi kanepeye uzanmış ekrana bakıyor, dinliyor. Bu du- } \\
\text { rumdan dolayı kendimi çok değersiz hissettim. }\end{array}$ \\
\hline & $\begin{array}{l}\text { Mesleğin Sorgu- } \\
\text { lanması }\end{array}$ & $\begin{array}{l}\text { Okulum gözetlerken isini bilen insanlarla iç içeyiz zaten ama benim isimi } \\
\text { bilmeyen velinin beni küçük görmesi isime olan saygısızlığı bizi mahvetti. } \\
\text { Derste bir şey söyledikten sonra veli telefondan mesaj atıyor hocam böyle de- } \\
\text { meseniz vs. gibi aksine kötü bir şey söylememize rağmen. Mesleğimizi öğret- } \\
\text { meye çalışan insanlar da çıkıyor }\end{array}$ \\
\hline & $\begin{array}{l}\text { Denetime Açık- } \\
\text { lık }\end{array}$ & $\begin{array}{l}\text { Evet, çünkü veliler genel olarak öğrencilerin ders dinlediği ortamda bulunu- } \\
\text { yorlar ve sürekli anlattıklarımı dinliyorlar bazen de ekrana bakıyorlar. Bu } \\
\text { durum çok rahatsız ediyor sürekli ders anlatma hissi oluyor sustuğum anda } \\
\text { öğretmen bilmediği için susuyormuş hissi uyandırıyor. }\end{array}$ \\
\hline \multirow[t]{3}{*}{$\begin{array}{l}\text { Öğretim } \\
\text { Süreci }\end{array}$} & $\begin{array}{l}\text { Veli Desteği/Ka- } \\
\text { rışması }\end{array}$ & $\begin{array}{l}\text { Hayır, ama 1. sınıf öğretmeni olduğum için velilerim öğrencilerime çŏ̆u kez } \\
\text { refakat ediyorlar. } \\
\text { Öğrenciler ve ben derse adapte olamıyoruz. Genellikle anneler kameranın } \\
\text { görüş açısında olmadan çocuklarına sorulan soruların yanıtlarını veriyorlar. } \\
\text { Böylelikle kazanımın kavratılıp kavratılamadığın anlayamıyorum. }\end{array}$ \\
\hline & Müdahale & $\begin{array}{l}\text { Öğrencilerin derste sürekli arkadaşlarına tanınan söz verme sırasını sayma- } \\
\text { ları örneğin x arkadaşıma bu kadar söz verdiniz bana ondan şu kadar eksik } \\
\text { söz verdiniz söylemleri artarak devam ediyor. }\end{array}$ \\
\hline & Destek Süreçleri & $\begin{array}{l}\text { Velilere yönelik çeşitli seminerler vs. Düzenlenerek ders sırasında dersin ya- } \\
\text { pıldığı ortamda bulunmalarının öğretmen, velinin kendi çocuğ̆ ve öğrenci- } \\
\text { ler penceresinden sakıncaları etraflıca anlatılabilir. Önemli olan uzaktan ile- } \\
\text { tişım araçları konusunda öğretmenlerin asli işlerini kolaylaştıracak yakla- } \\
\text { şımı esas almaktır. Var olan sürecin sağlıklı yaşama geçmesi için teknolojik } \\
\text { olarak öğretmenler ve öğrenciler desteklenmelidir. Süreci yalın 'denetim' } \\
\text { olarak ele alan yaklaşımların bir katkısı olmadı̆̆ı gibi daha fazla sorun alanı } \\
\text { üretecektir. }\end{array}$ \\
\hline
\end{tabular}




\begin{tabular}{|c|c|c|}
\hline \multirow[t]{2}{*}{ Rekabet } & Öğrenciler Arası & $\begin{array}{l}\text { Aileler, çocuklarının durumunu merak edip diğer çocukları kendi çocuğuyla } \\
\text { kıyaslamaya giriyor, bu da çocuklar arasında rekabete neden oluyor. }\end{array}$ \\
\hline & Veliler Arası & $\begin{array}{l}\text { Soru çözdürdü̈̆̈̈m sırada öğrencilere söz hakkı verirken, veli müdahale etti } \\
\text { çocuğuna "sesini yükselt, gerekirse bağır ki sana söz hakkı versin" diye. Söz } \\
\text { hakkını başkasına verdim diye o çocuk, arkadaşının sözünü sürekli kesip so- } \\
\text { ruyu kendi çözdü. Arkadaşını çözdüğ̈̈ soruya müdahale etmen hiç hoş de- } \\
\text { ğildi dediğimde babası söz hakkı verseydiniz bunu yapmak zorunda kalmazdı } \\
\text { diye derse tekrar müdahale etti. }\end{array}$ \\
\hline
\end{tabular}

Uzaktan eğitim süreçleriyle beraber öğretmenin öğrencileriyle olan ilişkilerini zora sokan, mesleki profesyonelliğini sorgulayan ve sınıf mahremiyetini ortadan kaldıran birçok problemin de başladığı söylenebilir. Öğretmenin sınıf mahremiyetinin ihlali ile başlayan süreç, velilerin öğretme-öğrenme süreçlerine aşırı müdahalesiyle öğrenciler yarış atına dönüştürülmüş, veliler ise kendi aralarında rekabet etmeye başlamışlardır. Öğretmenin kontrolünden çıkan süreç; eğitim-öğretim süreçlerinin nihai amacı olan öğrencilerin temel ihtiyaçları ve gelişimlerinin gözden kaçırılmasına, öğrencilerin bir bütün olarak gelişimlerinin akademik alanla sınırlandırılmasına ve öğrencilerin öğretmenleri ile diğer arkadaşları arasındaki insani ilişkilerin ortadan kaybolması da vesile olduğu düşünülebilir.

\section{Tema 3: Mahremiyetin İhlal Süreçleri}

Mahremiyetin ihlalinde sosyoekonomik nedenler, zorunlu koşullar içinde önemli bir yer almaktadır. Uzaktan eğitim süreçlerinin ihlaline yönelik yapılan bütün değerlendirmelerde, velilerin canlı ders esnasında aynı mekânda olmalarına yönelik şikâyetlerin öncelikli olduğu söylenebilir. Canlı ders esnasında velilerin aynı mekânda olmalarının arkasında, ailelerin eğitim gören çocuklarına farklı bir mekân bulamamalarının da önemli bir etkisi olduğu gözden kaçırılmamalıdır. Ayrıca sosyoekonomik şartlara bağlı olarak aynı mekânı paylaşmak zorunda olan aileler, canlı derslerde çocuklarını yönlendirerek büyük etapta kendi hedeflerini çocukları üzerinden gerçekleştirmek istemeleri ve içinde bulundukları zorunlu koşulları değiştirmek için eğitimi bir çıkış yolu olarak düşünmelerine bağlanabilir. 
Mahremiyeti ortadan kaldıran gerekçeler arasında zorunlu koşulların yanında, aile fertlerinin sürece dair meraklarının da etkili olduğu söylenebilir. Aile fertlerinin ya da okul idarecilerinin bilinçli gözetimlerini yönlendiren merakları, farklı nedenlere dayanmaktadır. Aile fertlerini yönlendiren nedenlerin; öğretmenlerin nasıl ders anlattığı, teknolojik araçlarla yapılan dersin doğası, kendi çocuğunun canlı derslerdeki performansı ile öğretmenle kendi çocuğu arasındaki ilişkinin yapısını öğrenmek şeklinde değerlendirilebilir. Okul idarecilerinin bilinçli gözetimlerinin arkasındaki değişkenin ise, öğretmenlerin derslerinin kontrolünü yapmak ve buna yönelik çetele tutmak şeklinde olduğu söylenebilir. Mesleki mahremiyeti ortadan kaldıran nedenler arasında yer alan izinsiz gözetlenmeler, farklı bireyler tarafından yapılmaktadır. Öğretmeler derslerini gözetleyen bireyleri, kendi meslektaşları, veliler, sınıf ortamında kalması gerek özeli başkalarıyla paylaşan öğrenciler ile sınıf ve derslerle ilgisi olmayan yabancı kişiler olarak sıraladıkları görülmektedir. Ayrıca gözetleme için kullanılan araç ve gereçlerin ise; bilgisayar, kamera, mikrofon, Zoom uygulaması, çevrimiçi ders işleme sistemi, tablet ve telefon şeklinde ifade edilmektedir.

Tablo 5: Mahremiyetin ihlal süreçlerine ilişkin kod ve örnek alıntılar

\begin{tabular}{|c|c|c|}
\hline Kategori & Kodlar & Örnek Alıntılar \\
\hline \multirow[t]{2}{*}{$\begin{array}{l}\text { Koşullar } \\
\text { ve Ne- } \\
\text { den }\end{array}$} & $\begin{array}{l}\text { Sosyoe- } \\
\text { konomik } \\
\text { Nedenler }\end{array}$ & $\begin{array}{l}\text { Bütün öğrencilerin kendine ait odası olmadığı için ailecek derse katılıyorlar. Zaman za- } \\
\text { man öğrencinin yerine cevap bile veriyorlar. Ben öğrencilerime ayrı bir odada gitmek } \\
\text { istediğinizi belirtin diyorum. Imkân yoksa kulaklık kullanalım annelerimiz bize yardım } \\
\text { ederse öğrenemeyiz diyorum. }\end{array}$ \\
\hline & Merak & $\begin{array}{l}\text { Okul yönetimi dersin işlenip işlenmediğini denetlemek için derse giriyor, birkaç saniye } \\
\text { sonra çıkıyor. Bu beni rahatsı etmiyor. Babalar da çocukların yanından çaktırmadan } \\
\text { izleyebiliyor. Aile dersi dinliyordur bunun sebebi öğretmenin derste nasıl anlattığını } \\
\text { merak etmesi veya konuya da ilgisi olabilir ya da öğrenciyi bur bakıma kontrol etmek } \\
\text { amacıyla da olabilir. }\end{array}$ \\
\hline \multirow{2}{*}{$\begin{array}{l}\text { Gözet- } \\
\text { lenme } \\
\text { Şekilleri }\end{array}$} & $\begin{array}{l}\text { Veli Gö- } \\
\text { zetimi }\end{array}$ & $\begin{array}{l}\text { Veliler dersi arka plandan doğrudan veya dolaylı olarak gözetliyor. Öğrenciler derste } \\
\text { iken Whats App mesajları bunu doğruluyor. }\end{array}$ \\
\hline & Araçlar & $\begin{array}{l}\text { Derse katılan öğrencilerin aileleri dersi ekranlardan "bilgisayar, cep telefonu" takip } \\
\text { ederek, istemeleri halinde kayda alabilmeleri mümkün görünüyor. }\end{array}$ \\
\hline
\end{tabular}

\section{Tartışma, Sonuç ve Öneriler}

$\mathrm{Bu}$ araştırmada, mesleki mahremiyet bağlamında uzaktan eğitim sürecinin etkileri incelenmeye çalışılmıştır. Mesleki mahremiyetin ihlallerinin öğretmenler üzerindeki psikolojik ve mesleki etkileri ile birlikte, mesleki 
mahremiyetin ihlalinin açık ve gizil amaçları ve araçları araştırmanın özünü oluşturmaktadır. Covid-19 salgını nedeniyle Millî Eğitim Bakanlığı' nın eğitim-öğretim faaliyetlerini uzaktan eğitim stratejileri ile yürütmeye başlaması, öğrenci-öğretmen-veli-yönetici ilişkilerinde farklılaşmalar meydana getirmiştir. Farklı platformlarda gerçekleşen uzaktan eğitim uygulamalarının etkisi, öğrencilerin sosyoekonomik imkânlarından da etkilenmiştir. Mesleki mahremiyet, yüz yüze eğitim sürecinde öğretmenlerin öğrencileriyle özel bir mekân olarak adlandırılan sınıftaki ilişkilerini, özel bir niteliğe bürüyen ve öğretmenleri diğer paydaşlar karşında güvende olmalarını sağlayan bir güvenlik bariyeri olarak nitelendirilebilir.

\section{Mahremiyetin İhlalinin Psikolojik Etkilerine İlişkin Bulguların Tartı- şılması}

Yabancılaşma (alienation) kavramı Marshall (1999:809) tarafından "bireylerin birbirlerinden ya da belirli bir ortam veya süreçten uzaklaşmaları" olarak tanımlanmıştır. Yabancılaşma; sosyoloji, psikoloji ve felsefi bağlamında ele alınabilecek bireysel ve toplumsal bir kavramdır (Akyıldız, 1998). Kavramın geçmişi, Hegel ve Marx'a kadar gitmekle beraber kavrama yüklenen anlamlar ile göstergeler de çeşitlenmektedir (Akyıldız, 1998; Sidorkin, 2004). Yabancılaşmanın göstergeleri ve yabancılaşmaya neden olan durumlar, eğitimin en önemli paydaşlarından olan öğretmenlerde farklı şekillerde açığa çıkmaktadır. Mahremiyetin ihlalinin psikolojik yansımaları; yabancılaşma, görmezden gelme, güvensizlik ve kaygı olarak sıralanabilir. Yabancilaşma; mekaniklik, kaybedilen heyecan ve kendisi olamama davranışları ile de temsil edilmektedir. Erjem'in (2005) lise öğretmenleri ile gerçekleştirdiği öğretmen yabancılaşması araştırmasında; güu̧süzlük, anlamsızlık, normsuzluk, uzaklaşma, iş tatminsizliği ve kendi kendine yabancılaşma en fazla karşılaşılan yabancılaşma göstergeleridir. Kesik ve Cömert (2014) ise öğretmenlerin en fazla güçsüzlük, yalıtılmışlık ve anlamsızlık boyutlarında yabancılaşma yaşadıklarını ortaya koymuştur. Öğretmenlerin mesleki yabancılaşması, branşlara (Kabakl1-Çimen, 2018), sosyo-demografik ve ekonomik değişkenlere göre de farklılık gösterebilmektedir.

Yabancılaşma, öğretmenlerin mesleklerini anlamsız ve sıkıcı bulmalarına da yol açabilmektedir (Atmaca, 2020). Mesleki anlamda öğretmenlik, 
beşerî sermayeye dayanan bir iştir. Beşerî sermayenin iş yapış tarzı, duygularına dayalıdır. Bu bağlamda Covid 19 salgını, öğretmenlerin sürekli temkinli ve tetikle olma halini artırmanın yanında, kendilerine de yabancılaşmalarına neden olduğu söylenebilir. Mesleki kaygı olarak da ele alınabilecek bu belirtiler; gerginlik, endişe ve evhamı da tetikleyebilmektedir (Gerçek, 2018). İfade edilen bu olumsuzlukların, eğitim sürecinin en önemli paydaşları olan öğrenci ve öğretmenlerin mekanik bir yapının dişlileri haline getirildiği gerçeğini gözler önüne sermektedir. Eğitim yönetimi alanındaki klasik kuramın; bilimsel yönetim, yönetim süreci ve bürokratik yaklaşımları (Seçtim ve Erkul, 2020) ile eğitim psikolojisinin klasik davranışçı kuramına bağlı yaklaşımların tamamıla insan odaklı bir mecra olan eğitimde uygulamaya geçirilemeyeceği, yaşanan problemlerden yola çıkılarak iddia edilebilir.

“Duygulara yabancılaşmanın” söz konusu olduğu süreçte, en önemli paydaşlardan olan öğretmenlerin de duygusal yabancılaşma yaşadıkları ve kendi varlıklarının en önemli sebebi olan öğrencilerinden uzaklaştıkları ifade edilebilir. Eğitim ortamlarında çalışan öğretmenlerin duyguları ve duygusal emeği, şu unsur tarafından etkilenebilmektedir: Bürokratik yapı, idareciler, meslektaşlar, öğrenciler ve veliler olarak sıralanabilir.

Görmezden gelme, eğitimde özellikle istenmeyen davranışlarla başa çıkma yöntemi olarak görülmektedir (Gangal ve Öztürk, 2019). Görmezden gelme, iletişim sürecinin kaynak ve alıcı kısmında yer alan paydaşların birbirine duyarsızlaşması olarak da ifade edilebilir. Öğretmenlerde mesleki mahremiyetin ihlali, uzaktan eğitim sürecinde özellikle öğrenci yakınları tarafından gerçekleştirilmektedir. Çevrim içi platformlarla birlikte, mekân olarak nitelendirilen sınıf ortamı, kamuya açık hale gelmiştir. Kamuya açık hale gelen sınıf, aynı zamanda burada paylaşılan farklı müfredat şekillerinin de sınıfın dışına çıkmasına neden olmuştur. Paylaşılan müfredat şekillerini, başta öğrenci olmak üzere birçok değişkene göre esnek hale getiren öğretmen; uzaktan eğitim süreciyle beraber risk alamayan, mekanik hale gelmiş ve duyguların ortadan kalktığı bir meslek erbabına dönüştürülmüştür.

Uzaktan eğitim sürecinin önemli bir öğretim aracı olan kameranın, öğretmelerin kullanımıyla sınırlandırılması, paydaşlar arasında güvensizliği ve kişisel mahremiyetin belirsiz kişilerce ihlalinin gerçekleşeceği korku- 
sunu artırmıştır. Güvensizlik, örgütsel sinizm ile de ilgilidir (Özdemir, Orhan ve Özkayran, 2018). Güvensizlik içerisinde kuşkuyu, güvenirliği ve kötüye kullanma riskini de barındırmaktadır. Bir diğer ifadeyle, sahnede olma ama sahnenin izleyen kısmını bilememe hali, belirsizliği tetiklemektedir. Belirsizliklerin tetiklediği bir diğer duygu durumunun kuşku olduğu görülmektedir. Bununla birlikte, araştırmada mahremiyetin ihlaline dikkat çeken ve süreçte ortaya çıkan kaygı durumu huzursuzluk, çekingenlik ve baskı hissetme temsilleri üzerinden ele alınmıştır.

\section{Mahremiyetin İhlalinin Mesleki Etkilerine İlişkin Bulguların Tartışıl- masi}

Mahremiyetin ihlalinin mesleki yansımaları; önyargı, mesleki özgürlük, mesleki saygınlık, öğretim süreci ve rekabet olarak görülmektedir. Önyargı, psikolojik bir kavram olmakla beraber bu araştırmada olgu ve olayları yanlış algılama bağlamında ele alınmıştır. Ayrıca, okullarda güven iklimi ve ön yargı arasında ilişki olduğu unutulamamalıdır (Erdoğan, 2016). Öğretmenlerin mesleki özgürlük alanları, okul ve sınıf alanlarında oluşabilmektedir. Uzaktan eğitim süreciyle öğretmenlerin mesleki özgürlük alanları, diğer paydaşlara da açılmıştır. Mesleki özgürlük alanlarının k1sıtlandığını düşünen öğretmenler, kısıtlanmışlık durumuyla karşı karşıya kaldıklarını düşünmektedir. Kısıtlanmışlık hissi, sürecin neden olduğu mekaniklikle ilgili olabilir.

Mesleki saygınlık ya da itibar, bir mesleğin tercih edilip ve sürdürülebilmesi açısından önemlidir. Yapılan “Türkiye'de Çalışma Hayatı ve Meslekler" araştırmasında, mesleki itibar skalası belirlenmiştir (Sunar, 2020). Bu skalada, öğretmenlik mesleği ön sıralarda yer almıştır. İfade edilen araştırmanın bulgularına rağmen, öğretmenlerin uzaktan eğitim süreci ile değersizlik hissi, mesleki yetkinliklerin sorgulanması ve denetime açık hale gelmelerinin elde edilen sonuçları olumsuz etkileyeceği unutulmamalıdır. Öğretim süreci, öğretmenlik mesleğinin ana çalışma alanıdır. Uzaktan eğitim süreciyle birlikte, öğretim sürecine öğretmen ve öğrencilerin yanında velilerin de doğrudan müdahil oldukları görülmektedir. Öğretmen ve öğ- 
renci mahremi olarak nitelendirilen öğretim sürecine, öğretmelerin profesyonelliğini sorgulayan ve sinıf atmosferini öğretmenin kontrolünden çıkaran veli profilinin dahil oluşu, öğretmenlerde rol karmaşasına ve otorite kaybına neden olduğu görülmektedir. Aynı zamanda, uzaktan eğitim süreciyle birlikte sınıf ortamının öğrenciler ve veliler arasında bir rekabet platformuna dönüştüğü de ifade edilebilir.

\section{Mahremiyetin İhlal Süreçlerine İlişkin Bulguların Tartışılması}

Uzaktan eğitim sürecinde mahremiyetin ihlali, kimi zaman mecburi kimi zamanda keyfi biçimde gerçekleşmektedir. Mecburi nedenlerin başında, öğrencilerin sosyo ekonomik düzeylerinden kaynaklı kendilerine ait bir çalışma odalarının bulunmamasıdır. Bir diğer zorunlu gerekçenin ise, küçük yaş gruplarındaki öğrencilerin öğretim sürecine dahil olabilmeleri için gerekli olan veli refakatidir. Öğretmenler tarafından problem olarak algilanan durumun ise, keyfi gözetlenme ve işlenen derse müdahaledir. Türkiye özelinde sosyoekonomik şartların dayattığı zorunluluklardan olan çocuk başına düşen oda sayısı, internet bağlantı imkânı ve bilgisayar erişiminin sınırlılığı, mahremiyetin ihlalini açık hale getirdiği söylenebilir. Duyarsızlaşma durumu, eğitim yönetimi alan yazınında mesleki tükenmişlik davranışları arasında yer almaktadır (Kalafat, 2017). Ayrıca, gözetlenmenin gerçekleştiği mecraların genel olarak canlı ders platformları oldukları görülmektedir.

\section{Öneriler}

Öğretmenlerin mesleklerini daha sağlıklı yürütebilmesi adına ülkenin de sosyoekonomik şartları düşünülerek, özellikle bürokrasinin öğretmenlerden beklentilerini net biçimde ortaya koyması gerekmektedir. Öğretmenlerden bu süreçte beklenen tam olarak nedir? Okul ile irtibatı bir biçimde sürdürebilmek mi, yoksa uzaktan eğitim ile akademik ve duyuşsal bilgi ve becerilerin eğitim-öğretimin yüz yüze olduğu dönemlerdeki gibi aynı oranlarda öğrencilere kazandırılmaya devam edilmesi mi? Bu seçeneklerin objektif biçimde masaya yatırılarak, değerlendirilmesi gerekmektedir. Diğer taraftan, öğretmenlere mahremiyetin ihlali konusunda hem duygu- 
sal hem de mesleki becerilerinin geliştirilebilmesi için kısa vadede bilgilendirme ve eğitimlerin yapılması gerekmektedir. Velilerin sosyoekonomik koşulları ile ilgili birçok mesele, ülkenin kalkınmışlığı ile ilgili olduğundan bu konuda kısa vadeli çözümler üretilmesi beklenmemekle birlikte, ailelerin en azından sorumluluklarına ilişkin okul bazlı veli bilgilendirme toplantıları yapılmalıdır. Araştırma sürecinde öğretmen, veli, öğrenci ve yöneticilere doğrudan ulaşma imkânı olmadığından ve gözlem yapabilme fırsatı bulunmaması, araştırmanın sınırlılığı olarak değerlendirilebilir. Bir diğer sınırlılık ise, uzaktan eğitim süreci ile ilgili araştırmaların yapılma ve yayınlanma süreçlerinin zorluklarına bağlı, yeterli alan yazının oluşmamasıdır. 


\title{
EXTENDED ABSTRACT
}

\section{Classroom Opening to the Public: Professional Pri- vacy and Surveillance in Distance Education*}

\author{
Taner Atmaca- Erdal Yıldırım-Turgay Öntaş \\ Düzce University-Aksaray University- Namık Kemal University
}

This study sought to reveal the experiences and views of teachers regarding the violation of privacy perception and digital surveillance emerging during distance and digital education activities which have become widespread with the Covid-19 pandemic. Together with digitalization; internet and objects connecting to internet have entered into nearly all areas of social and daily life and begun to be used commonly, which has brought along specific definitions. Surveillance emerging with accessibility which cannot be limited by time and space, has brought along an uncanny situation, state of anxiety and subjected the privacy to the view of strangers (Poyraz, 2019).

This is largely associated with being spied on. Panopticon which is one of the important concepts associated with modernity, expresses a society being spied on, in other words the spying of everyone from a center. It is one of the important matters that Foucault (2019) drives attention to. Foucault shows schools, prisons, factories and the army as examples to modern panopticons (Foucault, 2019; Şentürk and Turan, 2012; Şişman, 2019). In this context school is a surveillance center and it also has a disciplining power establishing a hegemony over bodies and minds. It is because surveillance also has a disciplining form. Schools which are among important encounter spaces of social life, have moved to the heart of digital environments with the Covid-19 pandemic and the fact that this moving has occurred abruptly rather than gradually is thought to have revealed specific pedagogical and sociological outcomes. Among these outcomes, the constant surveillance, inspection and controllability of teachers by other people and concerns and drawbacks emerging as a result are estimated to be primal. 
In addition to these statements, the study obtained the data concerning the purposes specified in the study via the semi-structured interview technic which was conducted with a total of 24 teachers working in different geographical regions and provinces in Turkey. The study used an integrated single case pattern based on the qualitative research approach. In analysis of the data the study used content analysis. Prior to creating the questions the study reviewed studies in the literature concerning the research problem and created the main questions on the basis of the key concepts specified. The questions created were finalized after consulting the expertise of three different academic members specialized in sociology and educational sciences as a result of a variety of warnings and revisions. The study conducted the interviews concerning the data to be collected, individually on platforms enabling online and instant meetings and recording the meetings within the date range of December 2020-January 2021. The participants submitted a consent form assuring that they took part in the study voluntarily via Google forms. In analysis of the data the study used descriptive analysis and content analysis technics.

The findings obtained confirm that privacy-related concerns of teachers have increased in the process. Opening the experiences concerning the teacher-student relationships which are thought to remain in the classroom to the public has concretized the professional privacy perception. In addition the study draws attention to alienation to the professin, higher anxiety, restlessness, anxiety caused by surveillance and intervention of families in the process. Indicators of alienation and situations leading to alienation come out in teachers who are one of the most important shareholders of teaching in different ways. Alienation is also represented by behaviors like being mechanic, lost excitement and being unable to be oneself. Together with online platforms, the classroom environment which is qualified as a space has opened to the public. The classroom which has opened to the public has also caused the different curriculum types shared here to go beyond the classroom. Teachers who make the curriculum types shared flexible according to many variables, primarily students, have turned into profession experts who are unable to take risk, have become mechanic and have no emotions due to the distance education process. Professional reflections of privacy violation are prejudice, professional freedom, professional respectability, educational process and competition. 
Prejudice is a psychological concept and this study discussed it in the context of case and misperception of events. Also we should keep in mind that confidence climate and prejudice are correlated in schools (Erdoğan, 2016). Professional respectability or dignity is important for the preferability and sustainability of a profession. A study entitled "Working Life and Professions in Turkey" determined a professional dignity scale (Sunar, 2020). The scale gives the professions of teaching prominence. Despite the findings of the aforementioned study, we should not forget that sense of worthlessness in teachers, questioning of their professional competence and their openness to supervision due to the distance education process will affect the results obtained negatively. In the distance education process privacy violation sometimes occurs compulsorily and sometimes arbitrarily. Of the compulsory reasons, the primary one is students' lack of a personal study room due to their socio-economic level. Another compulsory reason is a parent's company which is necessary for younger students to be included in the educational process. The situation that teachers perceive to be a problem is the arbitrary surveillance and intervention in the class.

The data suggesting that distance education destroys teachers' excitement of teaching is also remarkable. In addition we should stress that teachers perceive surveillance as an element of pressure. A limitation to the study was that the study only included the teachers and excluded other shareholders of school. What is exactly expected from teachers in this process? Are they expected to somehow be able to keep in touch with school or continue to add academic and affective knowledge and skills to students with distance education just like in the face-to-face education period? We need to discuss and evaluate these options objectively. Also we should inform and train teachers to develop their emotional and professional skills concerning privacy violation in the short term. Since most matters concerning the socio-economic conditions of parents are associated with the development of the country, we do not expect short-term solutions in this respect. However, we should organize school-based meetings at least concerning the responsibilities of families. 


\section{Kaynakça/References}

Akyavuz, E. ve Çakın, M. (2020). Covid-19 salgınının eğitime etkisi konusunda okul yöneticilerinin görüşleri. Turkish Studies, 15(4), 723-737. doi: 10.7827/TurkishStudies.44140.

Akyıldız, H. (1998). Bireysel ve toplumsal boyutlarıyla yabancılaşma. Süleyman Demirel Üniversitesi İktisadi ve İdari Bilimler Fakültesi Dergisi, 3, 163-176.

Atmaca, T. (2020). Öğretmenlerin kişilik tipleri ile mesleğe yabancılaşma arasindaki ilişki. Abant İzzet Baysal Üniversitesi Ĕ̆itim Fakültesi Dergisi, 20(1), 491-506. doi: 10.17240/aibuefd.2020.20.52925-613930

Baştürk, E. (2016). Panoptikon'dan post panoptikon'a gözetimin soykütüğ̈̈. Yayımlanmamış Doktora Tezi. Ankara Üniversitesi, Ankara.

Bauman, Z. (2018). Akışkan modernite (Sinan Okan Çavuş, Çev.). İstanbul: Can Yayınları. Çeviri tarihi: 2017

Bauman, Z. and Lyon, D. (2020). Akışkan gözetim (Elçin Yılmaz, Çev.). İstanbul: Ayrıntı Yayınları. Çeviri tarihi: 2013

Baudrillard, J. (2020). Simülakrlar ve simülasyon (Oğuz Adanır, Çev.). Ankara: Doğu-Batı Yayınları. Çeviri tarihi: 2005

Bennett, S. and Lockyer, L. (2006). Becoming an online teacher: Adapting to a changed environment for teaching and learning in higher education. Educational Media International, 41(3), 231-248. doi: $10.1080 / 09523980410001680842$.

Bozkurt, A. (2020). Koronavirüs (Covid-19) pandemi süreci ve pandemi sonrası dünyada eğitime yönelik değerlendirmeler: Yeni normal ve yeni eğitim paradigması. Açıöğretim Uygulamaları ve Araştırmaları Dergisi, 6(3), 112-142.

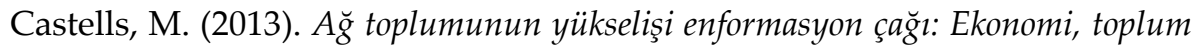
ve kültür (C1) (Ebru Kılıç, Çev.). İstanbul: İstanbul Bilgi Üniversitesi Yayınları. Çeviri tarihi: 2005

Chul-Han, B. (2019). Şeffaflık toplumu (Haluk Barışcan, Çev.). İstanbul: Metis Yayınları. Çeviri tarihi: 2017

Çelik, Z. (2020). Covid-19 salgının gölgesinde eğitim: Riskler ve öneriler. Ankara: Eğitim Bir-Sen.

Deleuze, G. (1992). Postscript on the society of control. October, 59, 3-7.

Erdoğan, C. (2016). Analysis on the relationship between trust culture and prejudices in primary schools, Eurasian Journal of Educational Research, 63, 153-168, http://dx.doi.org/ 10.14689/ejer.2016.63.9 
Erjem, Y. (2005). Eğitimde yabancılaşma olgusu ve öğretmen: lise öğretmenleri üzerine sosyolojik bir araştırma. Türk Eğitim Bilimleri Dergisi, 3(4), 395-417.

Foucault, M. (2019). İktidarın gözü (Işık Ergüden ve Osman Akınhay, Ed.). İstanbul: Ayrıntı Yayınları.

Gangal, M. ve Öztürk Y. (2019).Okul öncesi öğretmenlerinin sınıflarında istenmeyen davranışlar ve başa çıkma yolları. Eğitimde Nitel Araştırmalar Dergisi, 7(3), 1100-1118. doi: 10.14689/issn.2148-624.1.7c.3s.9m

Gerçek, M. (2018). Mesleki kaygı ve kariyer uyumluluğu arasındaki ilişkiler: Öğretmen adayları açısından bir inceleme. Trakya Üniversitesi Sosyal Bilimler Dergisi, 20(2). 297-312. 10.26468/trakyasobed.401010

Gündoğan, A.O. (2019). Başlangıçtan günümüze mahremiyetin idrak edilişi. Mahremiyet: Hayatın sırları ve sınrıları (Nazife Şişman, Ed.) (s.35-50) içinde. İstanbul: İnsan Yayınları.

Hazır, M. (2019). Siber toplumda mahremiyetin dönüşümü. Mahremiyet: Hayatın sırları ve sınrıları (Nazife Şişman, Ed.) (s.145-162) içinde. İstanbul: İnsan Yayınları.

Kabakl1-Çimen, L. (2018). Okul öncesi öğretmenlerinin mesleğe yabancılaşma düzeylerinin bazı değişkenler açısından incelenmesi. Kalem Eğitim ve Insan Bilimleri Dergisi, 8(2), 519-552. doi: 10.23863/kalem.2017.85

Kahraman, M. (2020). COVID-19 salgınının uygulamalı derslere etkisi ve bu derslerin uzaktan eğitimle yürütülmesi: Temel tasarım dersi örneği. IMÜ Sanat Tasarım ve Mimarlik Fakultesi Dergisi, 6(1), 44-56.

Kalafat, Ş. S. (2017). Üniversitelerdeki İngilizce okutmanlarını örgütsel iklim algıları ile mesleki tükenmişlik düzeyleri arasındaki ilişki. Yayımlanmamış Doktora Tezi. Hacettepe Üniversitesi Eğitim Bilimleri Enstitüsü, Ankara.

Kesik, F. ve Cömert, M. (2014). İlköğretim okullarında görev yapan öğretmenlerin işe yabancılaşma düzeylerine ilişkin algıları. İnönü Üniversitesi Ĕ̆itim Fakültesi Dergisi, 15(1), 27-46. doi: 10.17679/iuefd.99916.

Keyes, R. (2006). Hakikat sonrası çă̆: Günümüz dünyasında yalancılık ve aldatma (Deniz Özçetin, Çev.). İzmir: Delidolu Yayınları. Çeviri tarihi: 2004

Kılıç, H. (2009). Sosyo-ekonomik değişkenler açısından eğitimde yabancılaşma olgusu ve öğretmen. Yayımlanmamış Yüksek Lisans Tezi. Mersin Üniversitesi Sosyal Bilimler Enstitüsü, Mersin.

Lace, S. (2005). Introduction. The Glass Consumer (Susanne Lace, Edt.) (s.1-14) içinde. Bristol: Policy. 
Lyon, D. (2006). Günlük hayatı kontrol etmek: Gözetlenen toplum (Gözde Soykan, Çev.). İstanbul: Kalkedon Yayınları. Çeviri tarihi: 2006

Lyon, D. (2013). Gözetim çalışmaları: Genel bir bakış (Ali Toprak, Çev.). İstanbul: Kalkedon Yayınları.

Marshall, G. (1999), Sosyoloji Sözlüğ̈̈. Bilim ve Sanat Yayınları: Ankara.

McLuhan, M. (2005). Yaradanımız medya (Ünsal Oskay, Çev.). İstanbul: Turkuvaz Kitap. Çeviri tarihi: 2005

Okmeydan, S. (2017). Postmodern kültürde gözetim toplumunun dönüşümü: 'Panoptikon'dan 'sinoptikon' ve 'omniptikon'a. AJIT-e: Online Academic Journal of Information Technology, 8(30), 45-69.

Özbek, M. (2004). Kamusal alanın sinırları. Kamusal alan (Meral Özbek, Ed.) (s.19-90). içinde İstanbul: Hil Yayınları.

Özdemïr, T., Orhan, M. ve Özkayran, S. E. (2018). İlkokul ve ortaokul öğretmenlerinin örgütsel sinizm davranışları ile örgütsel sessizlik davranışları arasındaki ilişkinin incelenmesi. Atatürk Üniversitesi Kazım Karabekir Ĕ̈itim Fakültesi Dergisi, 37, 1-20.

Patton, M. (2014). Nitel araştırma ve değerlendirme yöntemleri (Mesut Bütün-Selçuk Beşir Demir, Ed.). Ankara: Pegem Yayınevi.

Poyraz, H. (2019). Mahremiyet, mahrumiyet, hürriyet. Mahremiyet: Hayatın sırları ve sınrıları (Nazife Şişman, Ed.) (s.21-34) içinde. İstanbul: İnsan Yayınları.

Rapanta, C., Botturi, L., Goodyear, P., Guàrdia, L. and Koole, M. (2020). Online university teaching during and after the covid-19 crisis: Refocusing teacher presence and learning activity. Postdigital Science and Education, 2, 923-945. doi: 10.1007/s42438-020-00155-y.

Seçtïm, H. ve Erkul, H . (2020). Yönetim yaklaşımları üzerine kuramsal bir değerlendirme. Management and Political Sciences Review, 2(1),18-50.

Sidorkin, A. M. (2004). In the event of learning: alienation and participative thinking in education, Educational Theory, 54(3), 251-262.

Sunar, L. (2020). Türkiye'de Çalışma Hayatı ve Meslekler Araştırması. https://tyap.net/mediaf/Calisma Hayati.pdf

Şişman, N. (2019). Sunuş. Mahremiyet: Hayatın sınırları ve sırları (Nazife Şişman, Ed.) (s.7-20) içinde İstanbul: İnsan Yayınları.

Turan, S., ve Şentürk, İ. (2012). Foucault'un iktidar analizi bağlamında eğitim yönetimine ilişkin bir değerlendirme. Kuram ve Uygulamada Ĕ̆itim Yönetimi, 8(2), 243-272. 
Yıldırım, A., ve Şimşek, H. (2013). Sosyal bilimlerde nitel araştırma yöntemleri. Ankara: Seçkin Yayınevi.

Yin, R. (2017). Durum çalışması araştırması uygulamaları (İlhan Günbayı, Çev.). Ankara: Nobel Yayınevi. Çeviri tarihi: 2017

\section{Kaynakça Bilgisi / Citation Information}

Atmaca, T., Yıldırım, E. ve Öntaş, T. (2021). Kamuya açılan sınıf: Mesleki mahremiyet ve uzaktan eğitimde gözetlenme. OPUS-Uluslararası Toplum Araştırmaları Dergisi, 18(Eğitim Bilimleri Özel Sayısı), 50045032. DOI:10.26466/opus.896351. 